\title{
Impact of service quality on customer satisfaction in Malaysia airlines: A PLS-SEM approach
}

\author{
Muhammad Shoaib Farooq ${ }^{\mathrm{a}, *}$, Maimoona Salam $^{\mathrm{b}}$, Alain Fayolle ${ }^{\mathrm{c}}$, Norizan Jaafar ${ }^{\mathrm{d}}$, \\ Kartinah Ayupp ${ }^{\mathrm{d}}$
}

${ }^{a}$ Institute of Business and Management, University of Engineering and Technology, Lahore, Pakistan

${ }^{\mathrm{b}}$ Faculty of Computer Science and Information Technology, Universiti Malaysia Sarawak, Malaysia

${ }^{\mathrm{c}}$ Department of Strategy and Organization, EMLYON Business School, Ecully, France

${ }^{\mathrm{d}}$ Faculty of Economics and Business, Universiti Malaysia Sarawak, Malaysia

\section{A R T I C L E I N F O}

\section{Keywords:}

Quality

Service quality

Malaysia airlines

Airline industry

Customer satisfaction

IPMA

PLS-SEM

AIRQUAL scale

\begin{abstract}
A B S T R A C T
This study is aimed to assess the quality of service provided by Malaysia Airlines and its impact on overall customer satisfaction. This study employed a convenience sampling method for collecting data from 460 respondents using a self-administered questionnaire, designed on five dimensions of AIRQUAL scale. Moreover, variance based structural equation modelling (PLS-SEM) was used for testing the proposed structural model. Findings of this study revealed that all five dimensions of AIRQUAL scale i.e. airline tangibles; terminal tangibles; personnel services; empathy and image have a positive, direct and significant impact on customer satisfaction of Malaysia Airlines. This study investigated the impact of service quality dimensions on customer satisfaction in Malaysia Airlines. Due to limited resources and time constraints this study involves respondents from Malaysia Airlines only; for that reason a comparative analysis of findings with other airlines was not possible; therefore it is considered a limitation of this study. Moreover, importance-performance map analysis (IPMA) was also performed for exploring the importance of various dimensions of service quality. Findings indicate that airlines should focus on all dimensions of service quality, with special focus on personnel services and image for enhancing their customer satisfaction. It is expected that findings of this study will help airlines to understand the role of various dimensions of service quality for enhancing their customer satisfaction.
\end{abstract}

\section{Introduction}

With the rapid advancements in competitive business environment, customer expectations and demands are also increasing, leading to a situation where many companies - especially airlines - find it difficult to retain their customers (Ali et al., 2015). Moreover failure to recognize true needs and wants of customers is also a barrier to providing high quality services (Izogo and Ogba, 2015). Today's competitive market situation have forced airlines to focus on cost reduction for achieving efficient business operations; however while doing so the element of service quality and customer satisfaction is often compromised (Boetsch et al., 2011).

Malaysia Airlines which was formerly known as Malaysian Airlines System (MAS) enjoys the prestige of being Malaysia's only national flag carrier. Company began as Malayan Airways Limited and flew its first commercial flight in 1947 (Zaid, 1995). However after Singapore's expulsion from Malaysia in 1972, airline's assets were divided in Singapore
Airlines and Malaysian Airline System (MAS), which is now known as Malaysia Airlines (Clarke, 2004; O'Connell and Williams, 2005). As the nation's only flag-ship carrier Malaysia Airlines enjoyed the monopoly status in domestic market since 1974-2000. However, with the liberalization of Malaysian domestic airline industry in early 2000, Air Asia have changed the face of Malaysian air travel industry (Hankins, 2016; Radovic-Markovic et al., 2017). Resulting in an intense competition between its incumbent Malaysia Airlines and other budget airlines such as Air Asia and Malindo Air (Ong and Tan, 2010).

Despite holding the recognition of being a leading airline in and to Asia from World Travel Awards $(2010-11,2013)$ these days Malaysia Airlines struggles to cut cost to compete with its rival low-cost airlines (Hankins, 2016; Ong and Tan, 2010; Radovic-Markovic et al., 2017). Since decades airline industry is facing challenges in terms of profitability and customer satisfaction all over the world (Forgas et al., 2012). However, Malaysia Airlines' financial troubles started exacerbating in 2014, after the loss of flight MH-370 and flight MH-17. Both

\footnotetext{
* Corresponding author.

E-mail addresses: sshoaibfarooq2@yahoo.com (M.S. Farooq), maimoonasalam1@yahoo.com (M. Salam), fayolle@em-lyon.com (A. Fayolle), jnorizan@unimas.my (N. Jaafar), akartinah@unimas.my (K. Ayupp).
} 